\title{
Carbon and nitrogen dynamics in elk winter ranges
}

\author{
ROMULO S.C. MENEZES, EDWARD T. ELLIOTT, DAVID W. VALENTINE, AND STEPHEN A. WILLIAMS
}

Author Menezes was a research fellow of the Brazilian CNPq at the time of this study, Elliott is an associate professor, and Williams is a research associate at the Natural Resource Ecology Laboratory, Colorado State University, Fort Collins, Colo., 80523; Valentine is a professor at the Department of Forest Sciences, University of Alaska, Fairbanks, Alaska, 99775-7200.

\begin{abstract}
Recent increases in elk (Cervus elaphus L.) herbivory and changes in hydrology towards drier conditions have contributed to declines in willow (Salix spp. L.) communities in the winter ranges for elk in Rocky Mountain National Park. In 1994, we constructed 12 large elk exclosures in 2 watersheds of the winter range for elk in the park, and conducted field experiments from 1995 to 1999 to investigate the effects of herbivory and proximity to surface water on the dynamics of $\mathrm{C}$ and $\mathrm{N}$. Litterfall biomass averaged 65.6 and $33.0 \mathrm{~g} \mathrm{~m}^{-2}$ inside and outside the exclosures, respectively. Elk herbivory increased $(P<0.05) \mathrm{N}$ concentration of willow litter from 1.25 to $1.49 \%$, but there were no differences in losses of $\mathrm{C}$ and $\mathrm{N}$ from litterbags placed in grazed and ungrazed plots in any of the growing seasons. Carbon losses from litterbags were higher in lower landscape positions $(P=0.001)$, in comparison to upper landscape positions. Shoot biomass of willow plants fertilized with $\mathrm{N}$ averaged $27.3 \mathrm{~g}$ and was higher $(\mathrm{P}<$ 0.05) than that of unfertilized plants, which averaged $20.2 \mathrm{~g}$, indicating that $\mathrm{N}$ availability limits plant growth in our study sites. Elk herbivory had no effect on soil inorganic $N$ availability, even though we estimated that the return of $N$ to the soil in grazed plots could be as much as $265 \%$ of the $N$ return in exclosed plots. In the long-term, greater return of $N$ to the soil combined with increased litter quality in the grazed plots could contribute to increases in $\mathbf{N}$ cycling rates and availability, and these changes could affect ecosystem structure and function in the winter range for elk in Rocky Mountain National Park.
\end{abstract}

Key Words: Willow, Salix, Carex, litterfall, litter decomposition, nitrogen availability.

Since 1968, elk (Cervus elaphus L.) numbers in Rocky Mountain National Park, Color. have been managed under a policy of natural regulation, which rests on the assumption that density-dependent mechanisms would result in an equilibrium between large ungulate herbivores and plant resources. During this period, elk numbers have increased from approximately 1,000 to about

The authors wish to thank J. Gensen, L. Hoogenstein, M. Kaye, R. Rochelle, M. Schrijvers, L. Schroeder, L. Zeigenfuss, J. Williams, and T. Wotan for assistance with field and laboratory work. We also thank F. Singer and D. Binkley for helping with the design and data analysis of some of the experiments. Helpful comments to the manuscript were provided by Therese Johnson, Ryan Monello, Gary Frasier and two anonymous reviewers. This study was primarily funded by the Biological Resources Division of the U.S. Geological Survey and also by the National Park Service.

Manuscript accepted 10 Oct. 00.

\section{Resumen}

El reciente incremento en la herbivoría del alce (Cervus elaphus L.) y los cambios en la hidrología hacia condiciones mas secas han contribuido a la disminución de las comunidades de "Willow" (Salix spp. L) en los pastizales de invierno para alces del Parque Nacional de las Montañas Rocallosas. En 1994 construimos 12 grandes exclusiones contra alce en 2 cuencas hidrológicas de pastizales de invierno para alce del parque y de 1995 a 1999 condujimos experimentos de campo para investigar los efectos de la herbivoría y proximidad de la superficie de agua en las dinámicas de $\mathrm{C}$ y $\mathbf{N}$. La biomasa de mantillo promedió 65.6 y $33.0 \mathrm{~g} \mathrm{~m}^{-2}$ dentro y fuera de las exclusiones respectivamente. La herbivoría del alce aumentó $(P<0.05)$ la concentración de $\mathrm{N}$ del mantillo de "Willow" de 1.25 a $1.49 \%$, pero no hubo diferencias en las pérdidas de $\mathbf{C}$ y $\mathbf{N}$ de bolsas con mantillo colocadas en parcelas con y sin pastoreo en ninguna de las estaciones de crecimiento. Las pérdidas de carbón de las bolsas con mantillo fueron mayores en las posiciones de terrenos bajos ( $P=$ 0.001), en comparación con las posiciones de terrenos altos. La biomasa de tallos de plantas de "Willow" fertilizadas con $\mathbf{N}$ promedió $27.3 \mathrm{~g}$ y fue mayor $(\mathbf{P}<0.05)$ que la de las plantas sin fertilizar, la cual promedió $20.2 \mathrm{~g}$, indicando que la disponibilidad de $\mathrm{N}$ limita el crecimiento de las plantas en nuestros sitios de estudio. La herbivoría del alce no tuvo efecto en la disponibilidad del $\mathbf{N}$ inorgánico del suelo, a pesar de que estimamos que el retorno de $\mathbf{N}$ al suelo en las parcelas con pastoreo pudiera ser tanto como el $265 \%$ del $\mathrm{N}$ retornado en las parcelas excluídas. A largo plazo, el mayor retorno de $\mathbf{N}$ al suelo, combinado con un aumento en la calidad del mantillo de las parcelas con pastoreo contribuir a incrementar las tasas de reciclaje de $\mathbf{N}$ y su disponibilidad, y estos cambios podrían afectar la estructura y función del ecosistema en los pastizales de invierno para alce del parque Nacional de la Montañas Rocallosas.

3,300 animals, and park managers are concerned about the effects of these increases on the soils and vegetation of the elk winter range within the park (Singer et al. 1998b).

Willow (Salix spp. L.) communities have reportedly been declining in elk winter ranges of the park during the last few decades (Hess 1993, Singer et al. 1998b), and several studies are currently being conducted to investigate the extent of these changes (R. Peinetti, pers. comm., 1999). Similarly, declines in willow populations have also been reported for Yellowstone National Park (Chadde and Kay 1991, Kay and Wagner 1994, Singer et al. 1998a). In addition to increased elk herbivory, 2 other factors have been proposed to explain these apparent 
declines in willow communities of Rocky Mountain National Park: (1) climates are warmer and drier this century, possibly resulting in lowered stream flows and less water availability to plants (Singer et al. 1998b); and (2) beaver populations have declined on the eastern slope of the park (Stevens and Christianson 1980), which may further contribute towards the drying of these ecosystems.

Large herbivores can significantly influence plant community structure and biogeochemical cycles within the soil-plant system (Frank et al. 1994, Frank and Groffman 1998, Hamilton et al. 1998, Schuman et al. 1999, Wijnen et al. 1999). Herbivores can influence nutrient cycling by removing plant biomass and returning more readily available nutrients to the soil (McNaughton et al. 1988, Frank et al. 1994, Hamilton et al. 1998), increasing soil $\mathrm{N}$ mineralization rates and plant $\mathrm{N}$ uptake (Frank and Groffman 1998, Wijnen et al. 1999), spatially redistributing nutrients within the landscape (McNaughton 1985, Afzal and Adams 1992, Russelle 1992), or decreasing the amount of litterfall and nutrient return to the soil in litter (Pastor et al. 1993).

Beaver (Castor canadensis Kuhl) can also influence plant communities and biogeochemical cycles of ecosystems. By building dams, beavers contribute to the entrapment of sediment and organic matter and modify water availability, nutrient cycling, and the dynamics of organic matter decomposition (Naiman et al. 1986, Naiman and Melillo 1984). It has been suggested that the observed declines in beaver populations in the eastern slope of Rocky Mountain National Park have contributed to a decrease in the surface area of water (ponds and streams) within the winter range of elk since the beginning of this century, therefore decreasing water availability for willows. These reductions in water availability could further reduce the ability of willow to respond to elk herbivory (Singer et al. 1998b) and could also alter the biogeochemical cycles of those ecosystems. However, the extent of the influences of these changes over the elk winter ranges of the park is unknown.

Plant-available $\mathrm{N}$ is usually a limiting element for plant growth in terrestrial ecosystems (Power 1977, Kiehl et al. 1997, Wijnen et al. 1999) and the cycling of $\mathrm{N}$ in these systems is linked to the $\mathrm{C}$ cycle by interactions between decomposers, plants, and herbivores (Aber and Melillo 1991, Pastor and Naiman 1992). There is no available information about the effects of elk herbivory or the reduction in surface water on the dynamics of $\mathrm{C}$ and $\mathrm{N}$ in the winter ranges of elk in Rocky Mountain National Park. This information is necessary for helping park managers formulate policies that will maintain herbivore populations at levels that are adequate for preserving the natural functioning of these ecosystems. Therefore, the objective of this study was to perform experimental field manipulations to investigate the effects of elk herbivory and proximity to surface water on the $\mathrm{C}$ and $\mathrm{N}$ cycles in the winter ranges of elk in the park.

\section{Methods}

\section{Study Sites}

The winter range for elk in Rocky Mountain National Park encompasses about 10,000 ha, which includes land within the eastern side of the park and private and national forest lands outside the park in the town of Estes Park and Estes Valley, Colo. (Singer et al. 1998b). Our study sites were located in 2 riparian ecosystems on the northeastern side of Rocky Mountain National Park: 1) Moraine Park, along the Big Thompson River watershed, at an elevation of 2,481 $\mathrm{m}$ and 2) Horseshoe Park, along the Fall River watershed, at an elevation of $2,598 \mathrm{~m}$. The latitude and longitude of the area of the watersheds are $105^{\circ} 36^{\prime} \mathrm{N}$ and $40^{\circ} 22^{\prime} \mathrm{W}$. The 2 watersheds are within $5 \mathrm{~km}$ of each other and have perennial alpine snowfields at their headwaters. Mean annual precipitation for the sites is $41 \mathrm{~cm}$ (Singer et al. 1998b) and peak stream flow usually occurs in early to mid-June (USDA 1995, 1996, 1997). The 30 -year average temperature for the adjacent Estes Valley ranges from 9 to $17^{\circ} \mathrm{C}$ during the 5-month growing season of May through September (Alstad et al. 1999). The study area consists of wet meadows dominated by willow (mainly Salix monticola L., S. geyeriana Anderss., and S. planifolia Pursh), other shrubs such as birch (Betula spp. L.), sedges (Carex spp. L.), rushes (Juncus balticus Willd.), and grasses (Phleum spp. L., Calamagrostis spp. Adans., Bromus spp. L., Poa spp. L.). The elk population of Estes Valley numbers about 3,300 animals, of which about one third generally spends the winter within the park (Larkins 1997, Singer et al. 1998b).

\section{Experimental Treatments}

In the wet meadows of both parks, 12 exclosures (30 m x $46 \mathrm{~m}$ each) were erected within willow communities along the rivers between August and November of 1994. Next to each exclosure, $30 \mathrm{~m} \mathrm{x} 46 \mathrm{~m}$ plots were chosen and marked off as paired plots open to grazing (grazed plots). The area within each exclosure was subdivided into $15 \mathrm{~m} \times 23 \mathrm{~m}$ sub-plots and 2 treatments were imposed throughout the period of the study: (1) $75 \%$ current annual growth removal (clipped plots), and (2) no clipping at all (ungrazed plots). The $75 \%$ current annual growth removal treatment was applied between January and April of 1995, 1996, 1997, and 1998, and consisted of clipping all forage shrubs and herbaceous plants in each sub-plot. All clipped plant biomass was removed from the exclosures. Therefore, each site consisted of: (1) grazed plot (outside the exclosure); (2) ungrazed plot; and (3) clipped plot (both inside the exclosure).

Eight sites (4 in Moraine Park and 4 in Horseshoe Park) were placed in areas with little or no beaver activity, and contained heavily browsed willow plants, which had their height suppressed by elk browsing (short willow). The other 4 sites ( 2 in each park) were located in nearby (about 1 to 2 $\mathrm{km}$ ) wetter areas, generally containing taller willow plants subjected to less browsing by elk (tall willow). The difference between the willow plants in the 2 areas (tall willow and short willow) was strictly morphological since the willow species composition of the communities in the 2 areas was the same. In half of the short willow sites ( 2 in each park), hydromanipulation treatments were imposed by placing sheet metal check dams on ephemeral stream channels both inside the exclosures and in the grazed plots. We expected these check dams to catch snowmelt and rain runoff through the spring and raise the water table at the sites. Twenty-five dams were installed in April and May 1995 and were relatively successful in holding additional water at these sites. The dams were intended to add water, but in no way was the treatment able to simulate water additions in the amounts accomplished by beaver dams on larger, permanent streams (Singer et al. 1997). In each exclosure and associated grazed plot, an average of 5 shallow $(0.5$ to $2 \mathrm{~m}$ ) wells were installed in the spring of 1995 for the purpose of monitoring groundwater levels. During early 1996 and 1997, 3 beaver dams were constructed near 2 sites within the wetter area of Moraine Park, but these dams were washed out during the spring flood of 1996 and 1997.

\section{Litterfall}

Litter was collected in each experimental plot during the fall of 1995, 1996, and 
1997, through the use of 15 greenhouse trays (totaling $\sim 2.3 \mathrm{~m}^{2}$ ) arranged in a $5 \mathrm{x}$ 3 regularly spaced grid $(9.1 \mathrm{~m} \times 15.9 \mathrm{~m})$. The grids were established randomly within each sub-plot before willow senescence began, and each tray was anchored to the ground using 2 or more large spikes. Litter was collected weekly from early September to late October until litterfall was complete. The litter was then composited within each experimental replication, sorted by genus and litter type, air dried, and weighed. Oven-dry corrections were applied within each category by drying a subsample at $60^{\circ} \mathrm{C}$. Litterfall biomass was calculated as oven dry mass per unit area. Total $\mathrm{N}$ and $\mathrm{C}$ content of litter was determined using a LECO CHN-1000 analyzer.

\section{Litter Decomposition}

During September and October of 1994, before the establishment of the exclosures, we collected litter material throughout the study area to generate a standard litter that was used in the decomposition experiments. Willow leaf litter was obtained by locating greenhouse trays directly under willow canopies throughout the study area (dominated by $S$. monticola, $S$. geyeriana, and $S$. planifolia) and collecting the leaves periodically. Carex litter was collected by clipping and collecting standing dead biomass. We dried all litter in a $35^{\circ} \mathrm{C}$ forced air oven, and subsamples ( $2 \mathrm{~g}$ ) from the 2 standard litter types (willow leaves and Carex tissue) were enclosed in $1 \mathrm{~mm}$ nylon mesh bags. These bags containing the standard litter were used in litter decomposition experiments to investigate the effects of herbivory, landscape position, and plant cover on the decomposition rates of willow and Carex litter during the growing seasons of 1995, 1996, and 1997. During the growing season of 1995 , we investigated the effect of herbivory on litter decomposition by randomly placing 4 bags of each litter type (willow leaves and Carex tissue) in the ungrazed plots within the exclosures and in the grazed plots outside the exclosures (no bags were placed in the clipped plots) for all of the 12 sites. The results from the 4 bags of each litter type within each treatment replicate were combined to reduce microsite variability within each of the 12 treatment replicates. In 1996 and 1997, we investigated the effect of herbivory, landscape position, and plant cover on litter decomposition. For this, we selected, in each of the ungrazed and grazed plots within the 12 sites, 2 willow shrubs located at 2 different landscape positions: (1) lower landscape positions, next to a stream or a pond, and (2) upper landscape positions, at least $10 \mathrm{~m}$ away from a stream or a pond and $0.5 \mathrm{~m}$ higher in the landscape than lower landscape positions. Bags of both willow and Carex litter were placed under the canopies of the selected shrubs ('willow canopies') and in open grass areas ('Carex plots') located within $2 \mathrm{~m}$ of the shrubs. Two bags of each litter type were placed within each treatment replicate and their results pooled in order to reduce microsite variability.

In all experiments, the litterbags were placed on the soil surface and left in the field during the entire length of the growing season (from late May until midSeptember). At the end of the season, they were collected, air-dried, weighed, ground to a fine powder to pass a 40 mesh sieve, and stored until analysis. Carbon and $\mathrm{N}$ in the decomposed litter were analyzed using a LECO CHN-1000 analyzer, and C and N losses were calculated in an ash-free dry weight basis by subtracting the amounts in the post-decomposition from the predecomposition litter.

\section{Elk Dung Quantification}

We estimated the amount of $\mathrm{C}$ and $\mathrm{N}$ returned to the soil in elk dung by counting the number of scat piles along $30 \mathrm{~m}$ transects within our experimental grazed plots, and measuring the concentrations of $\mathrm{C}$ and $\mathrm{N}$ in the dung. The survey was conducted after the elk herds left the winter range for the summer range during late spring 1997 . We selected 8 grazed plots (4 in each park) and established 4 randomly placed transects per plot. In each transect, we measured the distance from the scat piles to the transect, and calculated the density of piles per area. Only scat piles that were visually identified as from the previous fall and winter were counted. To estimate dry matter and $\mathrm{C}$ and $\mathrm{N}$ content in each dung pile we obtained 51 samples (26 from Horseshoe Park and 25 from Moraine Park) by collecting all dung from fresh piles during late Fall of 1997. After collection, the samples were oven-dried at $50^{\circ} \mathrm{C}$, weighed, ground to a fine powder, and sub-sampled for determination of moisture (oven-dried at $105^{\circ} \mathrm{C}$ ) and ash content $\left(500{ }^{\circ} \mathrm{C}\right)$. The concentrations of $\mathrm{C}$ and $\mathrm{N}$ in the dung were determined using a LECO CHN-1000 analyzer and expressed on an ash-free dry weight basis.

\section{Soil Characteristics and N Availability}

Soil samples $(0-15 \mathrm{~cm})$ were collected in July 1997 from the grazed, ungrazed, and clipped plots. Within each treatment replication, a total of 25 to 30 cores were randomly collected with a soil core sampler $2 \mathrm{~cm}$ in diameter and combined in a paper bag. After collection, the samples were taken to the laboratory, air-dried, and passed through a $2 \mathrm{~mm}$ sieve. Soil particle distribution was measured in each sample using the hydrometer method (Gee and Bauder 1986). Subsamples (10 g) of each sample were ground to a fine powder with a ball mill. The sand fraction $(>53 \mu \mathrm{m})$ of each sample was ground to a fine powder with a ball mill, for determination of particulate organic matter (POM) C and N (Cambardella and Elliott 1992). Total $C$ and $N$ in the total soil and sand fraction were determined with a LECO CHN-1000 analyzer.

In addition, during the summer of 1996 we collected soil samples $(0$ to $20 \mathrm{~cm}$ ) under willow trees and in associated open grass areas next (within $2 \mathrm{~m}$ ) to the trees. A total of 33 pairs of samples (shrub canopy plus open grass) were taken from the 12 ungrazed plots within the exclosures of Moraine Park and Horseshoe Park. The samples were air-dried and sieved through a $2 \mathrm{~mm}$ screen. Sub-samples $(10 \mathrm{~g})$ of each sample were ground to a fine powder with a ball mill, and total soil $\mathrm{C}$ and $\mathrm{N}$ were determined using a LECO CHN-1000 analyzer.

Soil moisture (0 to $14 \mathrm{~cm}$ ) measurements were performed weekly in 8 sites in Moraine Park and Horseshoe Park (4 in each watershed) by Time Domain Reflectometry (TDR) (Ledieu et al. 1986) with a Trase System model 6050x1 during the growing season of 1997 . The TDR rods were vertically placed in each measurement position and left there for the whole season. Within each site and grazing treatment, soil moisture was measured under willow canopies and in associated Carex plots next to the willow shrubs in both upper and lower landscape positions. Within 3 ungrazed plots in each park, soil temperature was measured using $\mathrm{HOBO}^{\circledR}$ temperature data loggers during the growing season of 1997. The loggers were wrapped with a thin plastic film to avoid damage by soil moisture, and were buried in a vertical position from 1 to $6 \mathrm{~cm}$ of depth. In each of the sites, we performed comparisons of soil temperature between (1) willow canopies and Carex plots and (2) streamside and upper landscape positions. The temperature measurements were performed every 15 minutes for periods of 7 to 14 days.

In 1995, 1996, and 1998 in situ soil N availability in the experimental plots was assessed using ion-exchange resin bags. Paired cation and anion resin bags made from nylon stockings and containing about $15 \mathrm{~cm}^{3}$ of exchange resins were placed 5 
$\mathrm{cm}$ beneath the soil surface (Binkley 1984). In 1995 and 1996, fifteen pairs of resin bags were placed in a regularly spaced grid $(9.1 \times 15.9 \mathrm{~m})$ within each treatment (grazed, ungrazed, clipped) in the 12 sites. To analyze the temporal variability of $\mathrm{N}$ availability, 2 sets of bags were placed in each of the 3 treatments during each of the growing seasons of 1995 and 1996. The first set was left in place from mid-June to mid-July, and the second set from mid-July to mid-August. A different experimental procedure was utilized in 1998, in which 6 pairs of resin bags were randomly placed within each of the 12 ungrazed and grazed plots (no bags were placed in the clipped plots), and left in the field from May to October. For all 3 years, after removal of the bags, the $\mathrm{N}$ adsorbed in the resins was extracted with $50 \mathrm{ml}$ of $2 \mathrm{M} \mathrm{KCl}$, and the extracts were frozen until analysis for $\mathrm{NO}_{3}{ }^{-}-\mathrm{N}$ and $\mathrm{NH}_{4}{ }^{+}-\mathrm{N}$ on an Alpkem automated spectrometer.

In 1997 and 1998, in situ measurements of net $\mathrm{N}$ mineralization were performed by conducting field soil incubations as described in Kolberg et al. (1997) using aluminum cores $15 \mathrm{~cm}$ long and $5 \mathrm{~cm}$ in diameter. During the 1997 growing season, cores were placed in upper and lower landscape positions within the 12 ungrazed and grazed plots of the 2 watersheds. Within each landscape position and grazing treatment, cores were placed under willow shrubs and in associated Carex patches within $2 \mathrm{~m}$ of the willow plants. Four cores were placed inside each treatment replicate to reduce micro-site variability. Cation and anion resin bags were placed in the bottom of each core to capture the inorganic $\mathrm{N}$ leached from the core. During the 1998 growing season, 6 open-top field soil incubation cores were placed within the ungrazed and grazed plots in 3 different 6week incubation periods (June to July, July to August, and August to October). Net soil $\mathrm{N}$ mineralized during the incubation periods was calculated by subtracting the initial amount of inorganic $\mathrm{N}$ in the soil from the final amount of inorganic $\mathrm{N}$ after the incubations, and the results were expressed in $\mathrm{g} \mathrm{N} \mathrm{m}^{-2}$.

\section{Nitrogen Fertilization}

In each ungrazed and grazed plot in the 12 sites, we placed 2 paired circular subplots (each with $2 \mathrm{~m}$ radius) around willow plants at the end of the growing season of 1998. Within each pair of circular subplots, we applied 2 fertilization treatments: (1) no fertilization, and (2) $10 \mathrm{~g} \mathrm{~N} \mathrm{~m}^{-2}$ as ammonium nitrate. During late July 1999, before the elk returned from the summer range at

Table 1. Litterfall biomass in ungrazed, clipped, and grazed plots of Moraine Park and Horseshoe Park during 1995, 1996, and 1997. Values represent means $(n=12)$ with standard errors in parentheses. Means within the same group followed by different letters are significantly different at $\mathbf{P}<0.05$.

\begin{tabular}{|c|c|c|c|c|c|c|}
\hline Treatment & $\begin{array}{l}\text { Willow (Salix } \\
\text { spp.) leaves }\end{array}$ & $\begin{array}{l}\text { Other shrub } \\
\text { leaves }{ }^{1}\end{array}$ & Herbs $^{2}$ & Wood & $\begin{array}{l}\text { Unidentified } \\
\text { material }\end{array}$ & $\begin{array}{c}\text { All } \\
\text { litter }\end{array}$ \\
\hline & \multicolumn{6}{|c|}{ 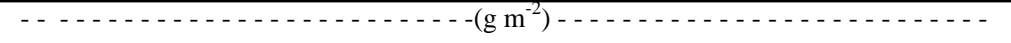 } \\
\hline \multicolumn{7}{|c|}{ (25 } \\
\hline Ungrazed & $32.9(9.8) \mathrm{a}$ & $5.9(2.7) \mathrm{ab}$ & $10.1(2.4)$ & $3.0(1.0)$ & $0.6(0.2)$ & $52.5(10.2) \mathrm{a}$ \\
\hline Clipped & $34.1(8.5) \mathrm{a}$ & $13.2(6.3) \mathrm{a}$ & $8.0(1.0)$ & $4.4(1.4)$ & $0.3(0.1)$ & 60.0 (8.9) a \\
\hline Grazed & $19.1(7.1) b$ & $1.7(0.6) b$ & $6.4(0.9)$ & $3.1(1.4)$ & $0.5(0.2)$ & $30.9(8.5) b$ \\
\hline \multicolumn{7}{|l|}{1996} \\
\hline Ungrazed & $55.0(13.6) \mathrm{a}$ & $9.1(3.9) \mathrm{ab}$ & $3.1(0.6)$ & $3.1(1.1)$ & $1.4(0.4)$ & 71.6 (12.6) a \\
\hline Clipped & $47.1(10.6) \mathrm{ab}$ & $18.3(8.6) \mathrm{a}$ & $2.690 .5)$ & $1.6(0.4)$ & $0.8(0.2)$ & $70.2(9.7) \mathrm{a}$ \\
\hline Grazed & $26.6(8.1) b$ & $3.7(0.8) b$ & $3.4(0.5)$ & $5.1(2.2)$ & $0.7(0.3)$ & $39.4(9.1) \mathrm{b}$ \\
\hline \multicolumn{7}{|l|}{1997} \\
\hline Ungrazed & $45.3(12.3) \mathrm{a}$ & $8.7(4.0) \mathrm{ab}$ & $14.3(3.3)$ & $3.1(1.0)$ & - & 71.5 (11.1) a \\
\hline Clipped & $41.6(10.4) \mathrm{a}$ & 15.5 (6.3) a & $7.2(0.7)$ & $2.2(0.7)$ & - & $66.4(10.1) \mathrm{a}$ \\
\hline Grazed & $15.9(6.0) \mathrm{b}$ & $3.0(0.9) b$ & $7.5(1.0)$ & $2.4(1.1)$ & - & $28.8(7.1) b$ \\
\hline
\end{tabular}

Mostly birch (Betula spp.) leaves.

${ }^{2}$ Litter material from forbs and Carex spp. combined.

higher elevations, willow shoots (current year growth) were collected from the plants inside the subplots, dried at $60^{\circ} \mathrm{C}$, weighed, and ground to a fine powder to pass a 40 mesh sieve. Concentrations of $\mathrm{C}$ and $\mathrm{N}$ in shoots were determined using a LECO CHN-1000 analyzer.

\section{Statistical Analyses}

Statistical analyses were performed using the SAS Statistical Package (SAS, Version 6.12, SAS Institute Inc., Cary, N.C., 1995). The data on litterfall, litter nutrient content, litter decomposition, soil characteristics, $\mathrm{N}$ availability, and $\mathrm{N}$ fertilization were analyzed using a split-plot factorial design where watershed was considered a random effect. Watersheds and height of willow plants were not significantly different $(\mathrm{P}<0.05)$ for any of the variables analyzed, therefore the data values from tall and short willow sites in both Moraine Park and Horseshoe Park were pooled (12 replications) in the analyses to determine the effect of browsing on litterfall and $\mathrm{N}$ availability, and the effects of browsing, proximity to surface water, and canopy position on litter decomposition. The data on soil nutrient content between willow canopies and open grass areas was analyzed using paired t-tests.

\section{Results and Discussion}

\section{Litterfall}

Litterfall biomass in the ungrazed and clipped plots was greater than in the grazed plots for the 3 growing seasons (Table 1). Across all growing seasons, litterfall biomass averaged 65.6 and $33.0 \mathrm{~g}$ $\mathrm{m}^{-2}$ inside and outside the exclosures, respectively. On average, willow leaves accounted for $58 \%$ of the litterfall biomass followed by herbs $(20 \%)$, other shrub leaves $(16 \%)$, wood $(5 \%)$, and unidentified material $(1 \%)$. However, the use of trays for collecting litterfall may underestimate the amount of grass litterfall, since a significant portion of the senescent tillers still remain attached to the plant and were not collected and counted as litter. Willow leaf litterfall in the ungrazed and clipped plots was greater than in the grazed plots during the 1995 and 1997 seasons, but in 1996 there were no significant differences between clipped and grazed plots (Table 1). Leaf litter from other shrubs, mostly birch (Betula spp.), was significantly lower in the grazed plots when compared to the clipping treatment inside the exclosures, but there were no differences between grazed and ungrazed plots. No treatment differences were observed for the amounts of herb or wood litter during the three growing seasons.

Inside the exclosures, even the removal of $75 \%$ of current annual growth in the clipped plots did not result in significant differences between the ungrazed and clipped plots during the growing seasons. We suggest this lack of difference between clipped and ungrazed plots occurred in part because the artificial clipping of willow did not satisfactorily simulate elk browsing. Other studies have demonstrated the limitations of clipping experiments to reflect accurately the natural patterns of herbivory (Paige 1999). Visual observations in our field plots suggested that clipped plants inside the exclosures were morphologically similar to the 
Table 2. Nitrogen content and carbon to nitrogen ratio of different litter types in ungrazed, clipped, and grazed plots of Moraine Park and Horseshoe Park in 1997. Values represent means $(n=12)$ with standard errors in parentheses. Means within the same group followed by different letters are significantly different at $P<0.05$.

\begin{tabular}{lcccc}
\hline \hline Treatment & $\begin{array}{c}\text { Willow (Salix } \\
\text { spp.) leaves }\end{array}$ & $\begin{array}{c}\text { Other shrub } \\
\text { leaves }^{1}\end{array}$ & Carex & Forbs \\
\hline $\begin{array}{l}\text { Nitrogen }(\%) \\
\text { Ungrazed }\end{array}$ & $1.25(0.10) \mathrm{b}$ & $1.23(0.15)$ & $1.40(0.11)$ & $1.79(0.13)$ \\
Clipped & $1.27(0.09) \mathrm{b}$ & $1.11(0.13)$ & $1.22(0.08)$ & $1.71(0.15)$ \\
Grazed & $1.49(0.08) \mathrm{a}$ & $1.09(0.11)$ & $1.23(0.09)$ & $1.82(0.12)$ \\
Carbon to nitrogen ratio & & & \\
Ungrazed & $45.8(3.2) \mathrm{a}$ & $48.5(12.0)$ & $37.2(2.9)$ & $31.0(3.0)$ \\
Clipped & $43.0(4.2) \mathrm{a}$ & $53.4(11.6)$ & $42.1(2.8)$ & $32.6(2.9)$ \\
Grazed & $37.7(3.1) \mathrm{b}$ & $49.9(14.3)$ & $43.5(3.1)$ & $31.4(2.6)$ \\
\hline
\end{tabular}

plants in the ungrazed treatment, regarding height and canopy structure, while the grazed plants were apparently more suppressed and shorter than the plants in the 2 treatments inside the exclosures. These patterns probably result from the additional damage to willow leaders caused by elk when striping off leaves from the plants, as compared to artificial clipping. On average, elk may browse on more than $70 \%$ of the leaders in each plant in our study sites, and may remove nearly $40 \%$ of the length of each leader (Singer et al. 1998b). Additional field observations from our experiments demonstrate that an average of $20 \%$ of the length of browsed willow leaders may die after elk browsing due to bark damage, while only $2 \%$ of the length of the leader may die in the case of artificially clipped plants (R. Peinetti, pers. comm., 1999). We suggest that the differences in litterfall observed between grazed and clipped treatments in our study may result from: (1) greater leader damage during elk browsing, in comparison to artificial clipping, and/or (2) greater increases in plant height in clipped plants, in comparison to grazed plants, due to differences in the patterns of tissue removal during elk browsing or artificial clipping, which may influence canopy architecture.

Willow leaf litter in the ungrazed and clipped plots had lower $\mathrm{N}$ content and higher $\mathrm{C}$ to $\mathrm{N}$ ratio than willow leaf litter in the grazed plots, but no significant treatment differences were found in litter from other shrubs, Carex, or forbs (Table 2). Similar to our findings, Alstad et al. (1999) reported that early season willow tissue $\mathrm{N}$ concentration in plants under elk herbivory in our sites was significantly higher than in plants protected from herbivory. Often, grazing leads to increases in plant tissue N (McNaughton 1985, Holland and Dettling 1990, Coughenour 1991, Hamilton et al. 1998) due to faster nutrient cycling and uptake by plants or a reduction in tissue biomass for allocation of N. Higher N concentration and lower C to $\mathrm{N}$ ratios in litter may lead to faster litter decomposition and greater nutrient availability (Ritchie et al. 1998, Irons et al. 1991). In our study site, the effects of elk herbivory on willow litter $\mathrm{N}$ concentration could lead to increases in the rate of litter decomposition and nutrient cycling, which could lead to changes in species composition and ecosystem functioning (Aber and Melillo 1991, Holland et al. 1992, Ritchie et al. 1998, Stohlgren et al. 1999).

\section{Litter Decomposition}

Losses of $\mathrm{C}$ and $\mathrm{N}$ from willow and Carex litter bags was not affected by grazing treatments in any of our experiments. However, in the 3 growing seasons, C losses from willow litter bags were higher than from Carex litter bags and, interestingly, $\mathrm{N}$ losses from willow litter were lower than from Carex litter (Table 3).

In 1996, C losses from litter bags were higher in streamside positions than in upper landscape positions, but no significant differences were observed for $\mathrm{N}$ losses during 1996 or $\mathrm{C}$ and $\mathrm{N}$ losses during 1997 (Table 4). Soil moisture is usually an

Table 3. Carbon and nitrogen losses from willow (Salix spp.) and Carex leaf litter bags in Moraine Park and Horseshoe Park during the growing seasons of 1995, 1996, and 1997. Values represent means $(n=12)$ with standard errors in parentheses.

\begin{tabular}{llc}
\hline Litter type & \multicolumn{1}{c}{ C loss } & N loss \\
\hline 1995 & $(\%)$ & $(\%)$ \\
Willow & $30.2(2.7)$ & $6.3(2.0)$ \\
Carex & $22.9(2.6)$ & $10.3(2.1)$ \\
P-value & N.S. 1 & 0.026 \\
1996 & & \\
Willow & $29.0(1.9)$ & $3.4(5.1)$ \\
Carex & $22.9(2.4)$ & $15.2(4.7)$ \\
P-value & 0.046 & 0.005 \\
1997 & & \\
Willow & $22.1(1.4)$ & $2.7(2.4)$ \\
Carex & $16.4(1.8)$ & $16.7(4.3)$ \\
P-value & 0.013 & 0.005 \\
\hline
\end{tabular}

Not significantly different at $\mathrm{P}<0.05$. important factor contributing to decomposition and, in general, litter decomposition increases with increasing soil moisture in semi-arid ecosystems (Schlesinger 1997). Higher C losses observed in streamside positions in our study are likely due to high-

Table 4. Carbon and nitrogen losses from litter bags placed in upper and lower landscape positions of Moraine Park and Horseshoe Park during the growing seasons of 1996 and 1997. Values represent means $(n=12)$ with standard errors in parentheses.

\begin{tabular}{lcc}
\hline Landscape position & \multicolumn{1}{l}{ C loss } & N loss \\
\hline & $(\%)$ & $(\%)$ \\
1996 & & \\
Streamside & $31.7(2.3)$ & $5.7(6.1)$ \\
Upper landscape & $20.3(1.9)$ & $12.8(6.0)$ \\
P-value & 0.001 & N.S. ${ }^{1}$ \\
1997 & & \\
Streamside & $18.1(1.9)$ & $6.5(4.2)$ \\
Upper landscape & $20.4(1.3)$ & $12.9(2.7)$ \\
P-value & N.S & N.S. \\
\hline
\end{tabular}

Not significantly different at $\mathrm{P}<0.05$.

er soil water availability (Fig. 1), suggesting that eventual reductions in surface water may lead to reductions in litter decomposition rates in our sites. However, no significant differences in willow or Carex litter decomposition were observed between streamside and upper landscape positions around the 2 beaver ponds in 1996. Average $\mathrm{C}$ and $\mathrm{N}$ losses from litter bags of the 2 litter types placed in streamside and upper landscape positions around the ponds were 36.4 and $2.9 \%$, respectively.

Litter bags placed under willow canopies lost significantly more $\mathrm{C}$ and $\mathrm{N}$ than bags placed in Carex plots (Table 5), even though soil moisture levels were slightly lower under willow canopies, compared to Carex plots, especially in Horseshoe park (Fig. 1). Average maxi-

Table 5. Carbon and nitrogen losses from litter bags placed under willow (Salix spp.) canopies and in Carex spp. plots in Moraine Park and Horseshoe Park during the growing seasons of 1996 and 1997. Values represent means $(n=8)$ with standard errors in parentheses.

\begin{tabular}{lcc}
\hline Position & C loss & N loss \\
\hline 1996 & $(\%)$ & $(\%)$ \\
Willow canopies & $35.7(1.7)$ & $24.2(1.8)$ \\
Carex plots & $7.7(2.9)$ & $-1.6(2.4)$ \\
P-value & 0.001 & 0.022 \\
1997 & & \\
Willow canopies & $23.1(1.5)$ & $15.5(1.7)$ \\
Carex plots & $16.0(3.5)$ & $3.4(3.5)$ \\
P-value & 0.001 & 0.012 \\
\hline
\end{tabular}




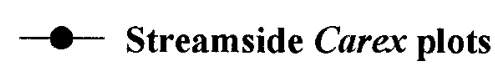

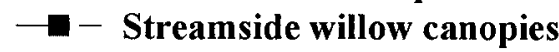

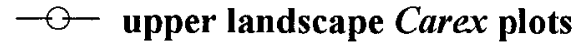

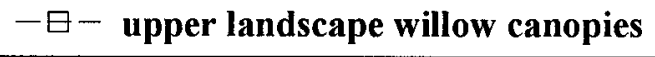

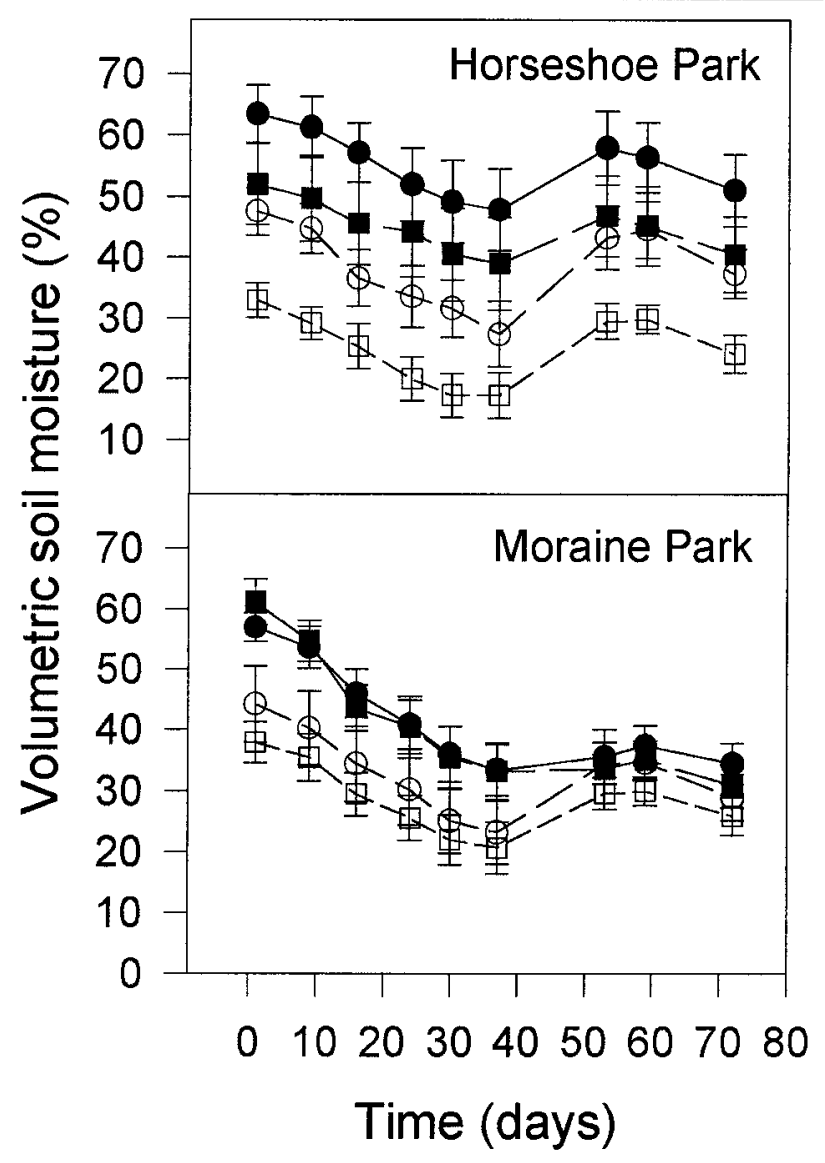

Fig. 1. Soil moisture (0 to $14 \mathrm{~cm})$ under willow canopies and in Carex plots in upper and lower landscape positions of Horseshoe Park and Moraine Park from early June to late August of 1997. Error bars represent standard errors of the means $(n=8)$.

mum soil temperatures from 1 to $6 \mathrm{~cm}$ in depth during the 1997 growing season were significantly lower under willow canopies than in Carex plots in both Moraine and Horseshoe parks (Fig. 2). These results indicate that the presence of willow shrubs has a significant influence on microclimatic conditions in our sites, decomposition and/or (2) Carex plants may have held litter bags off the soil, which may have let them dry out more and decompose less than bags placed under willow canopies.

\section{Return of $N$ to the Soil}

Based on the biomass and $\mathrm{N}$ content of aboveground litter in our sites (Tables 2 and 3), we calculated that the $\mathrm{N}$ return to the soil in aboveground litter during the 1997 growing season was greater in the ungrazed and clipped plots ( 0.83 and 0.82

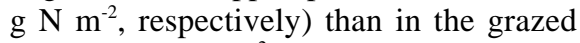
plots $\left(0.42 \mathrm{~g} \mathrm{~N} \mathrm{~m}^{-2}\right)$, excluding the contribution of $\mathrm{N}$ in wood litter in all treatments. Litter from willow, other shrubs, and herbs contributed to 62,17 , and $21 \%$ of the $\mathrm{N}$ returned to the soil in litter inside the exclosures, and 51, 16, and $33 \%$ of the $\mathrm{N}$ returned to the soil in litter within the grazed plots, respectively. Elk dung biomass deposited on the soil during the 1997-98 season averaged $42.2 \pm 6.2 \mathrm{~g} \mathrm{~m}^{-2}$ across all sites. This value is similar to those reported by Frank and McNaughton (1992), who found that average herbivore dung deposition during the 5 month season in the winter range of Yellowstone National Park was $76.9 \pm 30.1 \mathrm{~g} \mathrm{~m}^{-2}$. In our sites, average elk dung $\mathrm{N}$ concentration in the samples collected in late fall of 1997 was $2.0 \%$. Based on our results, we estimated that approximately $0.87 \pm 0.12 \mathrm{~g}$ $\mathrm{N} \mathrm{m}^{-2}$ returned to the soil in elk dung during the 1997-98 winter season in our study site. Therefore, the amount of $\mathrm{N}$ returned to the soil as elk dung plus aboveground plant litter averaged $1.3 \mathrm{~g} \mathrm{~m}^{-2}$ in the grazed plots. The estimated amount of $\mathrm{N}$ returned to the soil in elk urine in our sites, based on the diet and specific characteristics of the herd, could be approximately $98 \%$ of the $\mathrm{N}$ returned to the soil in dung (K. Schoenecker, pers. comm., 1999). Based on these estimates, after including the potential $\mathrm{N}$ inputs from urine, the total amount of $\mathrm{N}$ returned to the soil in the grazed plots could be as high as $2.2 \mathrm{~g} \mathrm{~N} \mathrm{~m}^{-2}$, which corresponds to $265 \%$

Table 6. Soil characteristics (0-15 cm) of ungrazed, clipped, and grazed plots of Moraine Park and Horseshoe Park in July 1997. Values represent means $(n=12)$ with standard errors within parentheses.

\begin{tabular}{|c|c|c|c|c|c|c|c|c|}
\hline Treatment & Total C & Total N & $\operatorname{POM}^{1} \mathrm{C}$ & POM N & Sand & Silt & Clay & $\mathrm{pH}^{2}$ \\
\hline Ungrazed & $50.3(9.0)$ & $3.38(0.63)$ & $15.9(3.5)$ & $0.81(0.19)$ & $523(59)$ & $209(40)$ & 152 (19) & $4.64(0.10)$ \\
\hline Clipped & $47.7(7.1)$ & $3.27(0.54)$ & $13.3(2.0)$ & $0.63(0.09)$ & $494(55)$ & $235(47)$ & $161(25)$ & $4.67(0.12)$ \\
\hline Grazed & $42.7(6.2)$ & $2.82(0.44)$ & $11.3(2.0)$ & $0.53(0.12)$ & 549 (37) & 234 (29) & 118 (19) & $4.60(0.11)$ \\
\hline
\end{tabular}

${ }^{\mathrm{T}}$ Particulate Organic Matter

${ }^{2}$ Measured in water $(2: 1$, water:soil) 


\section{Carex plots Willow canopies}

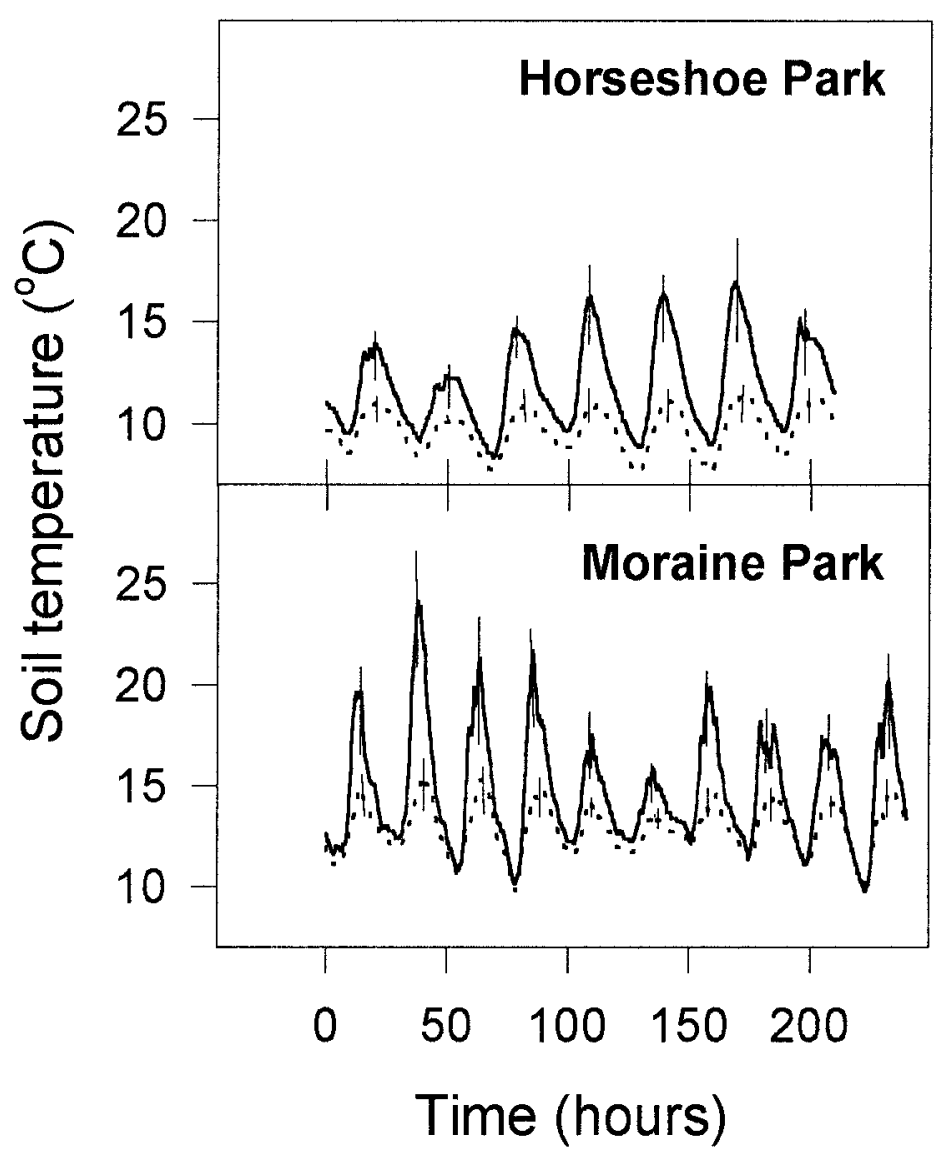

Fig. 2. Soil temperature $(1$ to $6 \mathrm{~cm})$ under willow canopies and in Carex plots in Horseshoe Park and Moraine Park during July 1997. Vertical lines represent the range of the $95 \%$ confidence interval for the means of maximum temperatures $(n=3)$.

of the $\mathrm{N}$ returned as aboveground litter in the exclosed plots. Our results are consistent with the findings of Frank and McNaughton (1992), who found that elk and bison populations in Yellowstone National Park excreted 0.81 to $4.60 \mathrm{~g} \mathrm{~N} \mathrm{~m}^{-2}$ year $^{-1}$, an amount that corresponded to roughly 4 times the amount of $\mathrm{N}$ returned in litterfall in their study site.

\section{Soil Characteristics and N Availability}

There were no significant differences in total soil C and N, POM C and N, soil texture, and soil $\mathrm{pH}$ between grazing treatments in our sites 4 years after the establishment of the exclosures (Table 6). Similar to our findings, Frank and Groffman (1998) found no differences in in soil total $\mathrm{C}$ and $\mathrm{N}$ between grazed plots and exclosed plots that had been protected from herbivory for 33 to 37 years in
$\mathrm{N}(0$ to $30 \mathrm{~cm})$ between soil samples taken in Carex plots or under willow canopies. Total soil $\mathrm{C}$ and $\mathrm{N}$ averaged 62 and $4.4 \mathrm{~g}$ $\mathrm{kg}^{-1}$ in Carex plots and 58 and $4.0 \mathrm{~g} \mathrm{~kg}^{-1}$ under willow canopies, respectively.

In all experiments with both ionexchange resin bags and field soil core incubations, there were no significant differences in soil $\mathrm{N}$ availability between grazing treatments during the years of the study. Several studies have reported increases in the rates of soil $\mathrm{N}$ mineralization with herbivory (McNaughton et al. 1988, Holland and Detling 1990, Frank and Evans 1997). Frank and Groffman (1998), reported that $\mathrm{N}$ availability in plots grazed by elk was $100 \%$ higher than exclosed plots. It is possible that the short time (4 years) since the establishment of the exclosures in our study did not allow for the development of detectable differences in soil $\mathrm{N}$ mineralization and availability between grazing treatments. Alternatively, since the explanations for the influences of herbivores on $\mathrm{N}$ availability are not quite well understood, other mechanisms may have contributed to the lack of differences in $\mathrm{N}$ availability between grazing treatments.

The assessment of $\mathrm{N}$ availability with ion-exchange resin bags during 1995 and 1996 indicated that, in general, both $\mathrm{NH}_{4}{ }^{+}-\mathrm{N}$ and $\mathrm{NO}_{3}{ }^{-}-\mathrm{N}$ availability were higher during early to mid-season and declined afterwards (Table 7). In 1998, there was only 1 resin bag incubation period, and the total amount of $\mathrm{N}$ adsorbed to the bags was slightly higher than the sum of both periods of either 1995 or 1996 , probably because the incubation period in 1998 was a few weeks longer. On average, the amount of $\mathrm{NH}_{4}{ }^{+}-\mathrm{N}$ adsorbed to the resin bags was 137 to $412 \%$ higher than $\mathrm{NO}_{3}{ }^{-}-\mathrm{N}$ during the 3 growing seasons.

Yellowstone National Park. In addition, we found no differences in total soil $\mathrm{C}$ and

Table 7. Inorganic nitrogen adsorbed to ion exchange resin bags during different incubation periods during 1995 and 1996, and from 1 incubation period during 1998. Values represent means (n =12) with standard errors within parentheses.

\begin{tabular}{|c|c|c|c|}
\hline Incubation period & $\mathrm{NO}_{3}{ }^{-}-\mathrm{N}$ & $\mathrm{NH}_{4}{ }^{+}-\mathrm{N}$ & $\mathrm{NO}_{3}{ }^{-}-\mathrm{N}+\mathrm{NH}_{4}{ }^{+}-\mathrm{N}$ \\
\hline 1995 & \multicolumn{3}{|c|}{ 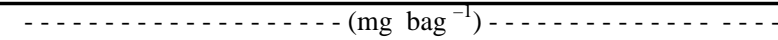 } \\
\hline June to July & $1.08(0.23)$ & $4.45(0.63)$ & $5.53(1.45)$ \\
\hline July to August & $0.64(0.32)$ & $2.12(0.44)$ & $2.78(1.29)$ \\
\hline P-value & 0.0151 & 0.001 & 0.001 \\
\hline \multicolumn{4}{|l|}{1996} \\
\hline June to July & $0.95(0.52)$ & $3.39(0.81)$ & $4.34(1.14)$ \\
\hline July to August & $1.05(0.55)$ & $1.44(0.53)$ & $2.49(0.87)$ \\
\hline P-value & N.S.2 & 0.001 & 0.001 \\
\hline \multirow{3}{*}{$\begin{array}{l}1998 \\
\text { July to October }\end{array}$} & & & \\
\hline & $3.01(0.55)$ & & \\
\hline & $7.29(1.98)$ & $10.30(2.43)$ & \\
\hline
\end{tabular}

${ }^{\mathrm{P}} \mathrm{P}$-value of comparisons between means of incubation periods.

${ }^{2}$ Not significantly different at $\mathrm{P}<0.05$. 
Table 8. Inorganic nitrogen mineralized during field soil incubations ( 0 to $15 \mathrm{~cm}$ ) using aluminum cores during 1997 and 1998. Values represent means for all treatments $(n=12)$ with standard errors within parentheses.

\begin{tabular}{llcc}
\hline \hline Incubation period $^{1}$ & $\mathrm{NO}_{3}{ }^{-}-\mathrm{N}$ & $\mathrm{NH}_{4}{ }^{+}-\mathrm{N}$ & $\mathrm{NO}_{3}{ }^{-}-\mathrm{N}+\mathrm{NH}_{4}{ }^{+}-\mathrm{N}$ \\
\hline 1997 & $\cdots \cdots$ & & \\
June to July & $0.11(0.04)$ & $0.55(0.15)$ & $0.66(0.16)$ \\
1998 & & & \\
June to July & $0.71(0.44)$ & $0.81(0.80)$ & $1.51(0.77)$ \\
July to August & $1.13(0.38)$ & $1.33(0.95)$ & $2.46(1.17)$ \\
August to October & $0.51(0.23)$ & $0.34(0.52)$ & $0.85(0.59)$ \\
\hline
\end{tabular}

Length of incubation period: $1997=4$ weeks; $1998=6$ weeks each period.

The higher proportions of soil $\mathrm{NH}_{4}{ }^{+}-\mathrm{N}$ could benefit plant productivity in our sites, since plants with an evolutionary history of grazing show elevated growth responses to ammonium relative to other

Table 9. Inorganic nitrogen adsorbed to ion exchange resin bags under willow (Salix spp.) canopies and in Carex spp. plots during different incubation periods of the 1995 and 1996 growing seasons. Values represent means $(n=12)$ with standard errors within parentheses.

\begin{tabular}{llc}
\hline \hline Position & June to July & July to August \\
\hline 1995 & $----\left(\mathrm{g} \mathrm{N} \mathrm{m}^{-2}\right)----$ \\
Willow canopies & $5.69(2.13)$ & $2.87(1.20)$ \\
Carex plots & $5.80(1.92)$ & $2.87(1.11)$ \\
P-value & N.S. & N.S. \\
1996 & & \\
Willow canopies & $4.98(0.77)$ & $3.07(0.55)$ \\
Carex plots & $4.01(0.68)$ & $2.42(0.37)$ \\
P-value & 0.018 & N.S. \\
\hline
\end{tabular}

${ }^{\mathrm{N}}$ Not significantly different at $\mathrm{P}<0.05$.

inorganic forms of $\mathrm{N}$, particularly when subject to defoliation (Ruess 1984, Ruess and McNaughton 1987, Hobbs 1996). Similarly to the results from the experiments with ion-exchange resin bags, the amounts of net $\mathrm{NH}_{4}{ }^{+}-\mathrm{N}$ mineralized in the soil cores were usually higher than $\mathrm{NO}_{3}{ }^{-}-\mathrm{N}$ (Table 8). In addition, total inorganic $\mathrm{N}$ in the soil was higher during early to mid-season during the 1998 growing season (Table 8). If plant uptake is higher

Table 10. Effects of nitrogen fertilization on willow (Salix spp.) growth and $\mathbf{N}$ assimilation during the growing season of 1999 . Values represent means $(n=12)$ followed by standard errors between parentheses.

\begin{tabular}{|c|c|c|c|c|}
\hline Treatment & Shoot length & $\begin{array}{c}\text { Shoot } \\
\text { biomass }\end{array}$ & $\begin{array}{c}\text { Shoot } \\
\text { concentration }\end{array}$ & $\begin{array}{c}\text { Amount of } \mathrm{N} \\
\text { per shoot }\end{array}$ \\
\hline $\mathrm{N}$ fertilizer $\left(10 \mathrm{~g} \mathrm{~N} \mathrm{~m}^{-2}\right)$ & $\begin{array}{c}(\mathrm{cm}) \\
28.6(1.4) \mathrm{a}^{1}\end{array}$ & $\begin{array}{c}(\mathrm{g}) \\
27.3(2.5) \mathrm{a}\end{array}$ & $\begin{array}{c}(\%) \\
2.25(0.05)\end{array}$ & $\begin{array}{c}(\mathrm{g}) \\
0.62 \stackrel{(0.06) \mathrm{a}}{ }\end{array}$ \\
\hline No fertilization & $22.5(1.1) \mathrm{b}$ & $20.2(2.4) b$ & $2.14(0.06)$ & $0.43(0.05) b$ \\
\hline
\end{tabular}

${ }^{\mathrm{N}}$ Means followed by different letters are significantly different at $\mathrm{P}<0.05$. and demand and enhance primary production and nutrient retention within the system (Myers et al. 1994).

Interestingly, the presence of willow had a significant effect on $\mathrm{N}$ availability in our experiments with ion-exchange resin bags. During both incubation periods of 1996 , the amounts of inorganic $\mathrm{N}$ adsorbed to resin bags located under willow canopies was higher $(P<0.05)$ than in bags placed in Carex plots (Table 9), but no significant differences were observed during 1995. The higher $\mathrm{N}$ availability may be a consequence of higher amounts of litter $\mathrm{N}$ inputs and higher rates of $\mathrm{N}$ loss from litter under willow canopies, as indicated by our findings in 1996.

The data from the $\mathrm{N}$ fertilization experiment demonstrated that willow growth in the winter ranges for elk is limited by $\mathrm{N}$ availability, independently of grazing treatment. Both inside and outside the exclosures, $\mathrm{N}$ fertilizer additions increased willow shoot length, shoot biomass, and the amount of $\mathrm{N}$ in the shoots (Table 10).

Based on our findings, we conclude that proximity to surface water had little effect on the dynamics of $\mathrm{C}$ and $\mathrm{N}$ in the winter ranges for elk during the period of our studies. In addition, we suggest that elk herbivory could lead to long-term increases in $\mathrm{N}$ availability in our sites, because of induced increases in both litter quality and return of $\mathrm{N}$ to the soil. Stohlgren et al. (1999) reported that exotic species were more likely to invade landscape patches higher soil $\mathrm{N}$ and moisture, which could lead to a decline in native plant species and ecosystem diversity (Billings 1990, D'Antonio and Vitousek 1992). Therefore, eventual increases in $\mathrm{N}$ availability in our sites due to elk herbivory could lead to changes in plant species composition and alter ecosystem functioning, because of shifts in the competitive interactions between plant species (Tilman 1982, 1988, Holland et al. 1992, Sterner 1994, Ritchie et al. 1998).

\section{Literature Cited}

Aber, J.D. and J.M. Melillo. 1991. Terrestrial
ecosystems. Saunders Coll. Publ. Philadelphia, Penn.

Afzal, M. and W.A. Adams. 1992. Heterogeneity of soil mineral nitrogen in pasture grazed by cattle. Soil Sci. 56:1160-1166.

Alstad, K.P., J.M. Welker, S. Williams, and M.J. Trlica. 1999. Carbon and water relations of Salix monticola in response to winter browsing and changes in surface water hydrology: an isotopic study using $\delta^{13} \mathrm{C}$ and $\delta^{18} 0$. Oecologia, 120:375-385.

Billings, W.D. 1990. Bromus tectorum, a biotic cause of ecosystem impoverishment in the Great Basin. p. 301-322. In: G.M. Woodwell (ed.), The earth in transition: patterns and processes of biotic impoverishment. Cambridge Univ. Press, Cambridge, UK.

Binkley, D. 1984. Ion exchange bags: factors affecting estimates of nitrogen availability. Soil Sci. Soc. Amer. J. 48:1181-1184.

Cambardella, C.A. and E.T. Elliott. 1992. Particulate soil organic-matter changes across a grassland cultivation sequence. Soil Sci. Soc. Amer. J. 56:777-783.

Chadde, S.W. and C.E. Kay. 1991. Tall willow communities in Yellowstone's northern range: a test of the "natural regulation" paradigm. p. 231-261. In: R.B. Keiter and M.S. Boyce (eds.), The greater Yellowstone ecosystem: redefining America's Wilderness Heritage. Yale University Press, New York, N.Y.

Coughenour, M.B. 1991. Biomass and nitrogen responses to grazing of upland steppe on Yellowstone northern winter range. J. Appl. Ecol. 28:71-82.

D'Antonio, C.M. and P.M. Vitousek. 1992. Biological invasions by exotic grasses, the grass/fire cycle, and global change. Annu. Rev. of Ecol. and Syst. 23:63-87.

Frank, D.A. and P.M. Groffman. 1998. Ungulate vs. landscape control of soil $\mathrm{C}$ and $\mathrm{N}$ processes in grasslands of Yellowstone National Park. Ecol. 79: 2229-2241.

Frank, D.A. and R.D. Evans. 1997. Effects of native grazers on grassland $\mathrm{N}$ cycling in Yellowstone National Park. Ecol. 78: 2238-2248. 
Frank, D.A. and S.J. McNaughton. 1992. The ecology of plants, large mammalian herbivores, and drought in Yellowstone National Park. Ecol. 73:2043-2058.

Frank, D.A., R.S. Inouye, N. Huntly, G.W. Minshall, and J.E. Anderson. 1994. The biogeochemistry of a north-temperate grassland with native ungulates: nitrogen dynamics in Yellowstone National Park. Biogeochem. 26:163-188.

Gee, G.W. and J.W. Bauder. 1986. Particlesize analysis. p. 383-411. In: A. Klute (ed.), Methods of soil analysis. Part $1.2^{\text {nd }}$ ed Agron. Monogr. 9. ASA and SSSA, Madison, Wisc.

Hamilton, E.W., M.S. Giovannini, S.A. Moses, J.S. Coleman, and S.J. McNaughton. 1998. Biomass and mineral element responses of a Serengeti short-grass species to nitrogen supply and defoliation: compensation requires a critical $[\mathrm{N}]$. Oecologia 116: 407-418.

Hess, K. 1993. Rocky times in Rocky Mountain National Park. Univ. Press of Colorado, Niwot, Colo.

Hobbs, N.T. 1996. Modification of ecosystems by ungulates. J. Wildl. Manage. 60:695-713.

Holland E.A. and J.K. Detling. 1990. Plant response to herbivory and belowground nitrogen cycling. Ecol. 71:1040-1049.

Holland, E.A., W.J. Parton, J.K. Detling, and L. Coppock. 1992. Physiological responses of plant populations to herbivory and their consequences for ecosystem nutrient flow. Amer. Natur. 140:685-706.

Irons, J.G., M.W. Oswood, R.J. Stout, and C.M. Pringle. 1991. Latitudinal patterns in leaf-litter breakdown-is temperature really important? Freshwater Biol. 32: 401-411.

Kay, C.E. and F.H. Wagner. 1994. Historical condition of woody vegetation on Yellowstone's northern range. p. 151-169. In D.G. Despain (ed.) Plants and their environments. National Park Serv., Tech. Report 93.

Kiehl, K, P. Esselink, and J.P. Baker. 1997. Nutrient limitation and plant-species composition in temperate salt marshes. Oecologia 111:325-330.

Kolberg, R.L., B. Rouppet, D.G. Westfall, and G.A. Peterson. 1997. Evaluation of an in situ net soil nitrogen mineralization method in dryland agroecosystems. Soil Sci. Soc. Amer. J. 61:504-508.

Larkins, K.F. 1997. Patterns of elk movement and distribution in and adjacent to the eastern boundary of Rocky Mountain National Park. $\mathrm{Ph} . \mathrm{D}$. Thesis, Univ. of Northern Colorado, Greeley, Colo.

Ledieu, J., P. de Ridder, P. de Clerk, and S. Dautrebande. 1986. A method of measuring soil moisture by time-domain reflectometry. J. Hydrol. 88:319-328.

McNaughton, S.J. 1985. The ecology of a grazing system: The Serengeti. Ecol Monogr. 55:259-294.

McNaughton, S.J., R.W. Reuss, and S.W. Seagle. 1988. Large mammals and process dynamics in African ecosystems. Biosci. 38:794-800
Myers, R.J.K., C.A. Palm, E. Cuevas, I.U.N. Gunatilleke, and M. Brossard. 1994. The synchronization of nutrient mineralization and plant nutrient demand. p. 81-116 In: P.L. Woomer and M.J. Swift (eds.), The biological management of tropical soil fertility. TSBF and Sayce Publishing, UK.

Naiman, R.J., and J.M. Melillo. 1984. Nitrogen budget of a sub-arctic stream altered by beaver (Castor canadensis). Oecologia 62:150-155.

Naiman, R.J., J.M. Melillo, and J.E. Hobbie. 1986. Ecosystem alteration of boreal forest stream by beaver (Castor canadensis). Ecology 67:1254-1269.

Paige, K.N. 1999. Regrowth following ungulate herbivory in Ipomopsis aggregata: geographic evidence for overcompensation. Oecologia 118:316-323.

Pastor, J. and R.J. Naiman. 1992. Selective foraging and ecosystem processes in boreal forests. Amer. Natur. 139:690-705.

Pastor, J., B. Dewey, R.J. Naiman, P.F. McInnes, and Y. Cohen. 1993. Moose browsing and soil fertility in the boreal forests of Isle Royale Nat. Park. Ecol. 74: 467-480.

Power, J.F. 1977. Nitrogen transformations in the grassland ecosystem. pp. 195-204. In: J.K. Marshall (ed.), The belowground ecosystem: a synthesis of plant-associated processes. Range Sci. Dept., Sci. Series No. 26, Colorado State Univ., Fort Collins, Colo.

Ritchie, M.E., D. Tilman, and J.M.H. Knops. 1998. Herbivore effects on plant and nitrogen dynamics in oak savanna. Ecol. 79: 165-177.

Russele, M.P. 1992. Nitrogen cycle in pasture and range. J. Prod. Agr. 5:13-23.

Ruess, R.W. 1984. Nutrient movement and grazing - experimental effects of clipping and nitrogen source on nutrient uptake in Kyllinga nervosa. Oikos 43:183-188.

Ruess, R.W. and S.J. McNaughton. 1987. Grazing and the dynamics of nutrient and energy regulated microbial processes in the Serengeti grasslands. Oikos 49:101-110.

SAS Institute. 1995. SAS User's Guide. Release 6.12. SAS Institute Inc., Cary, N.C.

Schlesinger, W.H. 1997. Biogeochemistry: An analysis of global change. Academic Press, San Diego, Calif.

Schuman, G.E., J.D. Reeder, J.T. Manley, R.H. Hart, and W.A. Manley. 1999. Impact of grazing management on the carbon and nitrogen balance of a mixed-grass rangeland. Ecol. Appl. 9: 65-71.

Singer, F.J., D.M. Swift, M.B. Coughenour, and J.D. Varley. 1998a. Thunder on the Yellowstone revisited: an assessment of management of native ungulates by natural regulation, 1968-1993. Wildl. Soc. Bull. 26: 375-390.

Singer, F.J., L.C. Zeigenfuss, R.G. Cates, and D.T. Barnett. 1998b. Elk, multiple factors, and persistence of $S$. monticola in national parks. Wildl. Soc. Bull., 26:419-428.
Singer, F.J., E.T. Elliott, M.B. Coughenour, J.M. Welker, D.W. Valentine, S.A. Williams, L.C. Zeigenfuss, K.P. Alstad, and R.S.C. Menezes. 1997. Large mammalian herbivores, plant interactions and ecosystem processes in five national parks. Second Ann. Rept. to Biol. Res. Div., USGS, Fort Collins, Colo.

Sterner, R.W. 1994. Elemental stoichiometry of species in ecosystems. p. 240-252. In: C.G. Jones and J.H. Lawton (eds.), Linking species and ecosystems. Chapman and Hall, New York, N.Y.

Stevens, D.R. and S. Christianson. 1980. Beaver populations on the East slope of Rocky Mountain National Park. Special Report to Rocky Mountain National Park, Estes Park, Colo.

Stohlgren, T.J., D. Binkley, G.W. Chong, M.A. Kalkhan, L.D. Schell, K.A. Bull, Y. Otsuki, G. Newman, M. Bashkin, and Y. Son. 1999. Exotic plant species invade hot spots of native plant diversity. Ecol. Monogr. 69:25-46.

Tilman, D. 1982. Resource competition and community structure. Princeton Univ. Press, Princeton, N.J.

Tilman, D. 1988. Plant strategies and the dynamics and structure of plant communities. Princeton University Press, Princeton, N.J.

U.S.D.A. Snow Survey Office (1995, 1996, and 1997). Snowpack data for Rocky Mountain National Park. Nat. Resources Conserv. Service. Lakewood, Colo.

Wijnen, H.J., R. van der Wal, and J.P. Bakker. 1999. The impact of herbivores on nitrogen mineralization rate: consequences for salt-marsh succession. Oecologia: 118: 225-231. 